\title{
Globalization and Economic Growth: Evidence from European Countries
}

\author{
Aderemi Timothy Ayomitunde - Ogunleye Akin George - Lucas \\ B. Ojo - Okoh Johnson Ifeanyi *
}

\begin{abstract}
:
This study examined the nexus between globalization and economic growth in European countries from 1990 to 2018 with the application of ARDL and Bounds test. Data was collected from the United Nations Conference on Trade and Development and World Development Indicator, respectively. The major findings that originated from this study are as follows. The lag value of economic growth has a significant positive relationship with its present value. Globalization index variables such as net FDI inflows and trade openness brought about economic growth in the European countries. This shows that the impact of globalization has been positive on the economies of the European countries in the last four decades. Furthermore, due to the emergence of these pertinent findings, the following recommendations are made for the policy makers in the European countries: globalization is a viable platform through which the European economies could achieve a sustainable economic growth in the short run. Therefore, whenever sustainable economic growth is the goal of the European policy makers, implementation of the policies that stimulate sporadic inflows of FDI should be embarked upon. Similarly, trade openness of these countries should be improved through exports of more value-added goods and services.
\end{abstract}

Key words: Globalization: FDI; Trade Openness and European Countries.

JEL classification: F43; F62; O15.

\section{Introduction}

Due to continuous rise in the level of interdependence of economies, integration of regions, disappearance of national borders and, more importantly, proliferation of digital technologies in the past few decades, globalization has become

* Aderemi Timothy Ayomitunde, Department of Economics, Olabisi Onabanjo University, Ago Iwoye, Nigeria <Aderemi.timothy@gmail.com>.

Ogunleye Akin George, Department of Economics, Osun State University, Osogbo, Nigeria. <akin.ogunleye@uniosun.edu.ng>.

Lucas B. Ojo, School of Technical Education, Yaba College of Technology, in Affiliation with University of Nigeria, UNN, Usukka, Nigeria.<lucasojobab@yahoo.com>.

Okoh Johnson Ifeanyi, Department of Financial Studies, National Open University of Nigeria, Abuja, <jokoh@noun.edu.ng>. 
an inevitable phenomenon in any country or region of the world. Meanwhile, globalization has affected every sphere of the society such as socio-economy, environment and politics (Baldwin \& Forslid, 2000; Obstfeld \&Taylor, 1997). Globalization and its corresponding impact on the various economies of the world have been recently highly controversial. (Jensen \& Sandström, 2011). In the same vein, globalization has been recently perceived in some quarters to orchestrate a conflict between developed and developing countries. This is because globalization represents a rapid expansion of business opportunities and advancement of technology in developed economies (Dollar, 2001). Whereas its impact has been attributed to the persistent rise in income inequality, environmental pollution, trade policy problems and widening of the gap between the rich and the poor in developing economies of Africa (Saibu \& Akinbobola, 2014; Okungbowa, Ewere \& Ose, 2014; Oyewale \& Amusat, 2013).

Nevertheless, it is now evident in this area that economies are increasingly integrated and networked through free flow of trade, labour, capital and technologies from one country to another. One of the most popular examples of the economic integration fuelled by globalization is interdependence of the countries under the European Union. As a result of different levels of specialization in each country, the countries in this region depend on one another through the free flow of labour, capital, technologies, goods and services. Despite the fact that globalization has played an indispensable role in integrating European Union into a single market, its aftermath effect on economic growth of the countries in this block remain ambiguous. It is instructive to state that debate about nexus between globalization and economic growth has faced diverging opinions in both the developed and developing countries alike. In the past studies, effects of globalization on different aspects of economies have been established as broad. Against this backdrop, (KOF Index of Globalization, 2012) categorised globalization into three strategic areas vis-à-vis economic, social and political globalization. This study focuses on economic globalization which is based on the flow of goods, services, capital and information across the countries of the world. In view of the above, this study examines the nexus between globalization and economic growth in the European countries in which the majority of the past studies have not fully explored. The reason behind is that recently only a few studies devoted to the analysis of globalization and economic growth with a focus on the sub-regions of Europe. For instance, Roberta \& Giovanni (2013) examined globalization and growth patterns in Eastern European Regions with the submission that the Eastern Europe with lower degree of globalization should be the central focus of regional growth policies, while Polasek \& Sellner (2011) addressed the nexus among exports, imports, FDI inward flows and economic growth in the EU-27 regions. In the same vein, the bulk of the studies in the past decade have focused on the sub-regional parts of Europe. See Kallioras 
\& Petrakos, 2010: Tondl \& Vuksic, 2007; Eller et al., 2006; Resmini, 2003; Gorzelak, 1998). As a departure from the past studies, the objective of this study is to examine the impact of globalization on economic growth in European countries. However, innovativeness and uniqueness of the presented study lie in addressing globalization and economic growth in Europe as a continent with an application of Autoregressive Distributed Lag (ADL) model, undermined by the majority of past studies. The study covers the period between 1990 and 2018 . The reason why as the base was chosen the year 1990 lies in the fact that most of the European countries, especially Eastern EU countries, have opened their markets to global capital for the first time in 1989. This led to sporadic inflows of FDI in EU countries.

Besides the introductory Section 1, the rest of this study is arranged as follows; the review of relevant literature is addressed in Section 2. Meanwhile, Section 3 presents the methodology, discussion of results and policy implication of the presented study.

\section{Literature Review}

\subsection{Theoretical Review}

Globalization has been conceptualized in scholarly works as a multidisciplinary phenomenon. This fact has made it recently very difficult for a single theory to explain the subject matter of globalization in a comprehensive way (Upali, 2017; Zoran, 2008). In view of the above, this paper provides a key summary of theoretical propositions on globalization, particularly from the economic perspective.

Globalization is a process whereby all artificial barriers hindering free flow of goods, services and production factors are in the global market removed. This free movement is highly facilitated by the advent of modern transport system and information/communication technologies. Therefore, McMichael (2000) asserted that globalization is integration of the global market and its expansion. Whereas globalization has been argued to be "a compression of time and space in a way that events in one part of the world have instantaneous effects on distant locations" (Mittelman, 2006, p. 64).

However, globalization is certainly driven by technological advancement in the $21^{\text {st }}$ century. This accelerates the contribution of globalization to important transformation of the economic system. This is substantiated in the following submission "... international economy is no longer divided vertically to separate national economies, but involves a number of different levels or types of market activities, which spread horizontally over a wider area of virtual space - replacing physical geography of national borders with quasi geography of market structures, transaction costs and informational cyber space." (Jakšić, 1997, p. 13). 
Consequently, the major players in this context are multinational corporations because they globally concentrate huge resources in economic activities and this has resulted in global civilization and market integration, respectively, in the world. Thus, as a strategic unit of economic agent, MNCs are continuously crowding out national models of economy (Ohmae, 1990).

\subsection{Empirical Review}

Studies regarding the nexus between globalization and economic growth have been generating a lot of arguments and controversies over the past few decades. This section presents various submissions of renowned scholars with a view to seeing the trend of this subject matter over the time and space. Parisa \& Hashem (2014) utilised the Generalized Method of Moments (GMM) technique to examine the relationship between globalization and economic growth within the Organisation of Islamic Cooperation (OIC) nations from 1980 to 2016. The authors posited that globalization from economic perspective impacted the economic growth statistically in the countries under investigation. In an explicit form, economies which have better educated workers and well developed financial system experienced a substantially positive effect of globalization. In the same vein, countries with high and middle incomes benefited from globalization while opposite was the case of low income countries. Rao \& Vadlamannati (2011) utilized KOF globalisation index to investigate the rate at which 21 African countries grew between 1970 and 2005 due to globalization. The study has reported that the positive effect of globalization on the growth of the selected countries was greater than that of investment. In another perspective, Gu \& Dong (2011) argued that the benefit or cost of financial globalization on economic growth is a function of the extent of the economies' financial systems' development. They have enunciated that volatility could displace growth if financial openness of countries didnot go along with any improvement in their financial system. In another related study, Villaverde \& Maza (2011) employed the techniques of Ordinary Least Square and Generalized Method of Moments in examining the nexus between globalization and economic growth in a sample of 101 economies over the time period from 1970 to 2005 . The finding from the study submitted that a long run convergence existed between globalization and economic growth in the selected countries. In other words, globalization resulted in economic growth in those countries. Meanwhile, Awuah \& Amal (2011) investigated how business performance was affected byglobalization in developing economies using a theoretical approach. The authors asserted that in spite of the fact that benefits of globalization have been substantially pronounced among the several players in the world, yet its aftermath effects on SMEs' efficiency have been surrounded with many controversies.

In another study focusing on the selected countries in South Asian sub-region, Muhammad (2015) applied the cointegration test, Ordinary Least Square, 
and Granger causality techniques to evaluate how globalization affected economic growth in those countries between 1981 and 2011. The findings that originated from the study stated that the growth rate of the economies in South Asia has been affected by globalization. Also, according to the Granger causality test, globalization-caused economic growth was present only in India. Whereas, there was a two-way feedback effect between globalization and economic growth in both Pakistan and Bangladesh. Similarly, Bhanumurthy \& Kumawat (2018) examined how globalization and economic growth were related in 7 countries in South Asia with the application of Panel VAR and Panel Causality approach. The findings from the study showed that the feedback effect from financial globalization to economic growth appeared to be weak in the South Asian sub-region. Meanwhile, the opposite was the case for the feedback from economic growth to financial globalization. But when it comes to individual countries, there is a variation in the results of the study. For example, output growth has caused financial globalization in the countries like Nepal, Maldives, India and Pakistan. But when it comes to the countries like Sri Lanka and Bhutan, based on the Granger causality test the foreign capital has caused the output to grow. And there was an indirect impact of foreign capital on the output growth in Bangladesh. While examining 29 OECD countries and rich economies, Bergh \& Karlsson (2010) utilized OLS and fixed effect in analysing the relationship between globalization and economic freedom during the period from 1970 to 2005. It was discovered that the government size has for the examined countries an inverse correlation with economic growth, implying that continuous trade openness, economic freedom and globalization are of a high necessity for these countries.

However, evidence from Africa in the work of Saibu \& Akinbobola (2014) indicated that globalization through trade openness has not affected economies of SubSaharan Africa significantly. This has been demonstrated while utilizing Vector Error Correction Modeling (VECM) to investigate interlink among globalization, foreign direct investment and economic growth in Sub-Saharan Africa. In another related African study, Asongu (2014) assessed the nexus between financial globalization and threshold of domestic financial condition from 15 African countries during the period from 1996 to 2009 with the application of OLS, LAD and quantile regression techniques. The study posited that financial globalization has not been of any particular benefit to financial depth in Africa.

\subsection{Globalization and Economic Growth in European and OECD Countries}

Dreher (2006) utilized OLS and GMM techniques to examine the nexus between globalization and economic growth of 123 countries during the period from 1970 to 2000. The author submitted that economic growth is promoted due to the advent of globalization in those countries. While examining 23 OECD countries, Chang \& Lee (2010) employed Pedroni's panel technique to assert that short-term 
causality is feeble and there is a long-term unidirectional causality which runs both from globalization and its dimension to growth. In the same vein, Chang et al. (2011) adopted panel cointegration to investigate globalization and economic growth in G7 countries during the period between 1970 and 2006. It was discovered that the overall globalization index and the social globalization index have a positive relationship with economic growth. In a related study, Gurgul \& Lach (2014) have examined 10 CEE Countries during the period between 1990 and 2009 via application of the Solow growth model. The authors submitted that globalization significantly facilitated economic growth in CEE countries. Meanwhile, CEE economies were stimulated by globalization in terms of the economic and social dimensions. Nevertheless, the political dimension of globalization is a minor player in economic growth of the new, transitionary EU member states.

Furthermore, Latif et al. (2018) utilized a simple regression analysis and the group mean estimator techniques to examine the nexus between globalization and economic growth in 5 BRICS countries. The authors argued that information and communication technology (ICT) and economic growth are positively associated in the long run. Foreign direct investment (FDI) and globalization have brought economic growth in the long run. Also, there was a bi-directional feedback effect among all the variables of interest in the study. While examining the linkage between financial market development and economic growth in some OECD and BRICS countries during the period between 1980 and 2015, José, António \& Cátia (2019) adopted KOF globalization index and the technique of ARDL bounds test. Consequently, the authors posited that financial globalization stimulated economic growth both in the short and long run. Whereas, political globalization impacted the model more significantly than other dimensions of globalization.

Conclusively, it has been observed that globalization and economic growth studies were recently ongoing across every region of the world. However, the recent few studies focusing on the European countries are yet to reach a consensus. Hence the relevance of this study.

\section{Methodology}

The presented study makes analytical use of secondary data covering the period from 1990 to 2018. FDI inflows data were sourced from UNCTAD investment report of the World Bank. In the same vein, data on other macroeconomic variables such as real GDP and trade openness were extracted from World Bank Development Indicator. 


\subsection{Research Design}

Our study adopts the ex-post facto research design. The ex-post facto research design is appropriate for this type of study because the main interest is to explore the viable relationship and describe how the explanatory variable predicts variation in the dependent variable.

\subsection{Model Specification}

This study adapted its model from the work of Parisa \& Hashem (2014) by eliminating some variables that are not relevant to this study.

$$
\mathrm{RGDP}=\mathrm{f}(\mathrm{TRO}, \mathrm{FDI})
$$

Linearizing model (1) brings about model (2) stated as follows:

$$
\operatorname{LnRGDP}_{\mathrm{t}}=\alpha_{0}+\alpha_{1} T R O_{t}+\alpha_{2} \operatorname{LnFDI}_{t}+u_{t}
$$

However, while estimating the relationship between globalization and economic growth in European countries, this study has employed Autoregressive Distributed Lag (ARDL) model. This model is utilized due to the different order of integration of the data set (Pesaran, Shin and Smith, 2001; Pesaran and Pesaran, 1997). Therefore, the model is stated as:

$$
\begin{gathered}
\Delta L n R G D P_{t}=\alpha_{0}+\sum_{i=1}^{p 1} \alpha_{1} \Delta \operatorname{LnRGDP}_{t-i}+\sum_{j=1}^{p 2} \alpha_{2} \Delta T R O_{t-j}+ \\
\sum_{k=1}^{p 3} \alpha_{3} \Delta L n F D I_{t-k}+u_{t}
\end{gathered}
$$

It is important to note that annual RGDP, representing the real gross domestic product on annual basis and measured in billions of US dollars, is employed as a proxy to economic growth and thereby serves as the dependent variable. Meanwhile, two of the relevant "KOF Globalization Index" inputs as calculated by Dreher, Gaston \& Martens (2008), i.e. FDI and trade openness, are employed as the independent variables. It is also worth noting that "KOF Globalization Index" has conceptualized globalization into economic, political and social spheres. Therefore, the economic dimension of this index emphasizes capital flow and trade openness. That is also why this study adopts FDI inflows and trade openness as proxies for globalization, since the subject of this study is an economic sphere of globalization. 
Consequently, FDI is Foreign Direct Investment net inflows on annual basis which is measured in millions of dollars and TRO is trade openness which is the addition of imports and exports as a percentage of GDP on annual basis. It is measured in percentage. The variable $\underline{u}$ represents other variables which were excluded from the model but nevertheless affect economic growth. It is assumed to be serially uncorrelated. Ln represents a natural logarithm. The variable t represents the time period of analysis, i.e. ranges from 1990 to 2018.

The a priori expectation is stated as follows; $\alpha_{1}, \alpha_{2} \& \alpha_{3}>0$.

It is should be noted that this study utilizes data from all the European countries as a continent rather than pooling the data from individual countries.

\subsection{Results and Discussion}

Tab. 1: Descriptive Statistics of Annual Data Series (1990-2018)

\begin{tabular}{llll}
\hline Descriptive Statistics & LnFDI & LnRGDP & TRO \\
\hline Mean & 12.73154 & 9.252302 & 64.64715 \\
Median & 12.87689 & 9.253320 & 61.51300 \\
Maximum & 13.62151 & 10.01644 & 86.62800 \\
Minimum & 11.21864 & 8.088618 & 49.57900 \\
Std. Deviation & 0.736702 & 0.634322 & 12.41275 \\
Skewness & 0.755496 & 0.482506 & 0.374903 \\
Kurtosis & 2.421115 & 2.062129 & 1.654070 \\
Jarque-Bera & 4.254582 & 2.942630 & 3.857322 \\
Probability & 0.119160 & 0.229623 & 0.145343 \\
Sum & 496.5303 & 360.8398 & 2521.239 \\
Sum. Sq. Deviation & 20.62373 & 15.28987 & 5854.902 \\
Observation & 28 & 28 & 28 \\
\hline
\end{tabular}

Source: Authorial computation.

Regression analysis is premised on the assumption of the data series' normal distribution. It is therefore important to examine the descriptive statistics of the variables of interest with a view to establishing the asymptotic distribution of the data. The estimated results in Table 1 show that log of net FDI inflows in Europe during the 28-year period possesses the minimum value of 11.2 million and the maximum value of 13.6 million, respectively. In the same vein, the mean value stands at 12.7 million with a standard deviation of 0.7 million. This indicates that FDI data deviated from the both sides of mean by 0.7 million. But the dispersion of data is moderate because its mean value is greater than the standard deviation. 
Similarly, skewedness of FDI data has a value of 0.755496 and the kurtosis value stands at 2.421115. This shows that the data is positively skewed and in agreement with the symmetrical distribution assumption because the value of its kurtosis is close to 3 .

Moreover, the log of RGDP data measuring economic growth cover the period of 28 years with the minimum and maximum values of 8.1 billion and 10 billion, respectively. The variable has a mean value of 9.3 billion and a standard deviation of 0.6 billion. Despite the fact that FDI deviated from both sides of the mean by 0.6 million, the dispersion is still moderate because the value of the corresponding standard deviation is less than the mean value of data. In the same vein, the data is positively skewed with the kurtosis value close to3. This implies that FDI data is nearly symmetrical in terms of its distribution.

\section{Tab. 2: Unit Root Test}

\begin{tabular}{llllll}
\hline ADF Test & & & & & \\
\hline Variables & Level & Probability & 1st Diff & Probability & Remark \\
\hline LRGDP & $-2.941145 * * *$ & 0.7505 & $-2.943427 * * *$ & 0.0008 & $\mathrm{I}(1)$ \\
LFDI & $-2.941145 * * *$ & 0.2266 & $-2.943427 * * *$ & 0.0001 & $\mathrm{I}(1)$ \\
TRO & $-2.943427 * * *$ & 0.0000 & & & $\mathrm{I}(0)$ \\
\hline PP Test & & & & & \\
\hline Variables & Level & Probability & $\mathbf{1 s t}$ Diff & Probability & Remark \\
\hline LRGDP & $-2.941145 * * *$ & 0.8932 & $-2.943427 * * *$ & 0.0002 & $\mathrm{I}(1)$ \\
LFDI & $-2.941145 * * *$ & 0.1827 & $-2.943427 * * *$ & 0.0001 & $\mathrm{I}(1)$ \\
TRO & $-2.943427 * * *$ & 0.0000 & & & $\mathrm{I}(0)$ \\
\hline
\end{tabular}

Source: Authorial computation.

Note: $* * * \% 5$ level.

Consequently, trade openness which covers the period of 28 years has a minimum value of $49.6 \%$ and a maximum value of $86.7 \%$. It was observed that the mean value of the data is greater than its standard deviation. The implication is that thedispersion of the data is moderate. Also, the data has a positive skewedness and the kurtosis value less than 3 . This shows that the data partially deviate from the symmetrical distribution assumption.

Spurious or nonsense regression is always an aftermath effect of time series data with a unit root problem. In order to overcome this problem in a study that employs time series data (like this), an attempt was made to examine stationarity properties of the data via application of the standard Augmented Dickey-Fuller (ADF) andPhillips-Perron (PP) tests. It could be inferred from Table 2 that FDI and RGDP 
data were not stationary in their native form. In another words, these variable possess a unit root problem. Whereas, trade openness data was stationary at level, implying that the data is free from a unit root problem.

Meanwhile, it is important to state that the variables of interest to this study are the combination of (1) and (0), respectively. In a scenario like this, an ARDL model had been suggested as the appropriate analytical technique. See (Pesaran, Shin and Smith, 2001; Pesaran and Pesaran, 1997).

Tab. 3: ARDL Bounds Test

\begin{tabular}{lll}
\hline Test Statistic & Value & K \\
\hline $\begin{array}{l}\text { F-statistic } \\
\text { Critical Value Bounds }\end{array}$ & 0.655915 & 2 \\
\hline Significance & I0 Bound & I1 Bound \\
\hline $10 \%$ & 3.17 & 4.14 \\
$5 \%$ & 3.79 & 4.85 \\
$2.5 \%$ & 4.41 & 5.52 \\
$1 \%$ & 5.15 & 6.36 \\
\hline
\end{tabular}

Source: Authorial computation.

Note: Null Hypothesis: No long-run relationships exist

The presented study utilizes Bounds Test to examine if there exists a long run relationship among the globalization index and economic growth variables. However, the estimated results from Table 3 show that the Null Hypothesis, which stipulates no long-run relationship, could not be rejected due to the fact that the upper and lower Critical Value Bounds are greater than the F-Statistic at all levels of significance. This implies that no cointegrating relationship existed among the variables in the model. Therefore, globalization index variables and economic growth do not have a long run relationship in Europe. Hence, short run relationship between globalization and economic was estimated.

\section{Tab. 4: VAR Lag Order Selection Criteria}

\begin{tabular}{llllll}
\hline Lag & LogL & LR & FPE & AIC & SC \\
\hline 0 & -964.2491 & NA & $4.36 \mathrm{e}+19$ & 53.73606 & 53.86802 \\
1 & -875.1119 & $158.4662 *$ & $5.10 \mathrm{e}+17 *$ & $49.28399 *$ & $49.81183 *$ \\
2 & -866.3844 & 14.06088 & $5.24 \mathrm{e}+17$ & 49.29913 & 50.22285 \\
3 & -860.4274 & 8.604591 & $6.40 \mathrm{e}+17$ & 49.46819 & 50.78779 \\
\hline
\end{tabular}

Source: Authorial computation. 
Note: Sample: 1990-2018, Included observations: 28, * indicates lag order selected by the criterion, LR: sequential modified LR test statistic (each test at 5\% level), FPE: Final prediction error, AIC: Akaike information criterion, SC: Schwarz information criterion.

From the above table, all the information criteria showed that a lag of one would be appropriate for the model. The optimal lag length selection is important in ARDL model because it shows how the effect of a variable in the previous year affects the current year.

\section{Tab. 5: Short Run Relationship between Globalization and Economic Growth in European Countries}

\begin{tabular}{llll}
\hline Variable & Coefficient & t-statistics & P-value \\
\hline LnRGDP(-1) & $1.264096^{* * *}$ & 8.477003 & 0.0000 \\
LnFDI & $0.084859^{* *}$ & 2.220659 & 0.0197 \\
TRO & 0.001864 & 0.479156 & 0.6352
\end{tabular}

R-Squared $\quad 0.979752$

Source: Authorial computation.

Note: Dependent Variable: LnRGDP, *Significant at $10 \%$, **Significant at 5\%, *** Significant at $1 \%$.

Table 4 shows the ARDL results of the short run relationship between globalization index variables and economic growth in European countries. All the explanatory variables followed the study's priori expectation. Meanwhile, R-Squared is 0.979752 . This implies that approximated $98 \%$ of deviation in the dependent variable, i.e. economic growth, was explained by the globalization index and $\mathrm{RGDP}(-1)$ in the model, leaving $2 \%$ unexplained as a result of random chance. The implication of this is that the model is relatively good for the analysis.

However, the lag value of economic growth has a significant positive relationship with the present value. This shows that the past economic growth led to present economic growth in European countries. In the same vein, FDI and economic growth have a positive relationship in European countries. The relationship is significant at 5\% level of significance. A unit change in net LnFDI inflows leads to $0.08 \%$ increment in economic growth in European countries. Also, economic growth and trade openness have a positive relationship, but the relationship is not significant at $10 \%$ level of significance. From the above, it could be inferred that globalization leads to economic growth in European countries. This finding is validated by the submissions of José, António \& Cátia (2019) in the panel analysis of 10 economies, Latif et al. (2018) in BRICS countries, Parisa \& Hashem (2014) in a similar studies in OIC economies, Chang et al. (2011) in G7 countries, Rao \& Vadlamannati (2011) in 21 African countries, Villaverde \& Maza (2011) in the sample of 101 economies, Polasek and Sellner (2011) in European Union (EU-27) countries, and Rao et al. (2011) in Malaysia, Thailand, India 
and Philippines. This is despite the fact that different methodologies were adopted. Whereas, the finding in the study contradicts the proposition of Saibu and Akinbobola (2014), Bourdon, Mouel \& Vijil (2011) and De Matteis (2004).

\subsection{Diagnostic Tests}

While evaluating the diagnostic test in this study, the distribution of residual value of the estimated model was shown in the above figure. It is worth noting that the distribution is positively skewed with the value of kurtosis not far from 3 . In the same vein, its J-B value is 1.782822 but its probability is not significant at $5 \%$ critical value. The implication is that the residual value of the model is fairly distributed.

\section{Fig. 1: Diagnostic Tests}

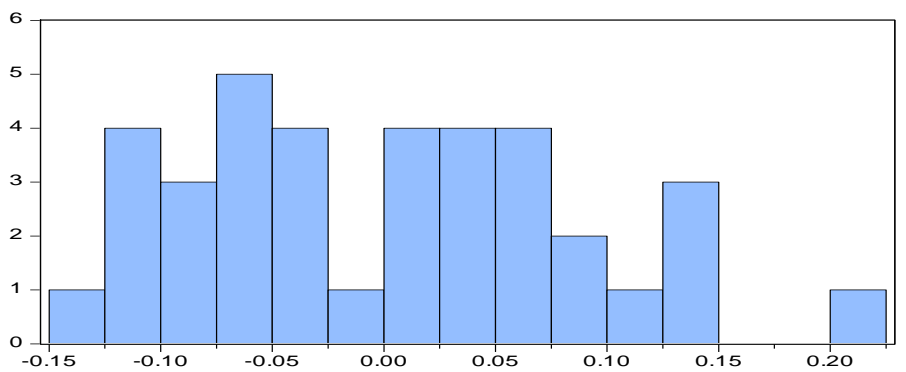

\begin{tabular}{|lr|}
\hline \multicolumn{2}{|l|}{ Series: Residuals } \\
Sample 1982 2018 \\
Observations 37 \\
Mean & $-4.44 \mathrm{e}-16$ \\
Median & 0.007007 \\
Maximum & 0.202520 \\
Minimum & -0.127107 \\
Std. Dev. & 0.085918 \\
Skewness & 0.382181 \\
Kurtosis & 2.243578 \\
& \\
Jarque-Bera & 1.782822 \\
Probability & 0.410077 \\
\hline
\end{tabular}

Source: Authorial computation.

Tab. 6: Heteroskedasticity Test: Breusch-Pagan-Godfrey

\begin{tabular}{llll}
\hline F-statistic & 0.737348 & Prob. F(5,31) & 0.6012 \\
Obs*R-squared & 3.932608 & Prob. Chi-Square(5) & 0.5592 \\
Scaled explained SS & 1.716499 & Prob. Chi-Square(5) & 0.8868 \\
\hline
\end{tabular}

Source: Authorial computation.

As presented in the above table, the result of the heteroskedasticity test shows that the probabilities of both the F-statistic and the observed R-squared are 0.6012 and 0.5592 , respectively. They are greater than 0.05 . This suggests that the model is homoscedastic since the null hypothesis of no heteroscedasticity could not have been rejected.

\section{Tab. 7: Breusch-Godfrey Serial Correlation LM Test}

\begin{tabular}{llll}
\hline F-statistic & 1.131138 & Prob. F(2,29) & 0.3365 \\
Obs*R-squared & 2.677482 & Prob. Chi-Square(2) & 0.2622 \\
\hline
\end{tabular}

Source: Authorial computation.

As presented in the above table, the value of both the F-statistic and the observed $\mathrm{R}$-squared are 0.3365 and 0.2622 , respectively. This shows that this residual value 
is free from serial correlation due to the fact that these probability values are higher than 0.05 . This implies that the null hypothesis $\left(\mathrm{H}_{\mathrm{o}}\right)$ of no serial correlation could not be rejected.

\section{Conclusion and Recommendation}

This study examined the nexus between globalization and economic growth in European countries during the period from 1990 to 2018 with the application of ARDL and Bounds test. Consequently, the following are the major findings that originated from this study. The lag value of economic growth has a significant positive relationship with its present value. In other words, the past economic growth led to present economic growth in European countries. Globalization index variables such as net FDI inflows and trade openness brought about economic growth in European countries.

Furthermore, due to the emergence of these pertinent findings, the following recommendations are made for the policy makers in the European countries as follows: globalization is a viable platform through which the European economies could achieve a sustainable economic growth in the short run. Therefore, whenever a sustainable economic growth is the goal of the European policy makers, implementation of the policies that would stimulate sporadic inflows of FDI should be embarked upon. Similarly, trade openness of these countries should be improved through export of more value-added goods and services to all the world regions.

\section{References}

Afzal, M., 2007. The impact of globalization on Economic Growth of Pakistan. The Pakistan Development Review 46, 723-734.

Awuah, G. M., Amal, M., 2011. Impact of globalization: The ability of less developed countries' (LDCs') firms to cope with opportunities and challenges. European Business. European Business Review 23, 120-132.

Asongu, S., 2014. Financial development dynamic thresholds of financial globalization: evidence from Africa. Journal of Economic Studies 41, 166-195.

Bhagwati, J., 2004. In defense of globalization: With a new afterword. Oxford University Press.

Bhanumurthy, N. R., Kumawat, L., 2020. Financial Globalization and Economic Growth in South Asia. National Institute of Public Finance and Policy.

Bergh A, Nilsson, T., 2011. Globalization and Absolute Poverty - A Panel Data Study. IFN Working Paper No. 862, 2011.

Bourdon, H. M., Mouel, L. C., Vijil, M., 2017. The Relationship between Trade Openness and Economic Growth: Some New Insights on the Openness 
Measurement Issue. Presented at XIIIème Congrès de l'Association Européenne des Economistes Agricoles (EAAE).

Chang, C. P., Lee, C. C., 2010. Globalization and economic growth: A political economy analysis for OECD countries. Global Economic Review 39, 151-173.

Chang, C.-P., Lee, C. C., Hsieh, M. C., 2011. Globalization, real output and multiple structural breaks. Global Economic Review 40, 421-444.

China Investment Yearbook, 2006. The Ministry of Commerce of People's Republic of China; Beijing; China Statistics Press.

Collier, P., Dollar, D., 2002. Globalization, Growth, and Poverty: Building an inclusive World Economy. Oxford University Press, New York, NY.

De Matteis, D. A., 2004. International Trade and Economic Growth in a Global Environment. Journal of International Development 16, 575-588.

Dreher, A., 2006. Does globalization affect growth? Evidence from a new index of globalization. Applied Economics 38, 1091-1110.

Dreher, A., Gaston, N., Martens, P., 2008. Measuring globalisation: Gauging its consequences: Springer Verlag.

Gu, X. H., Dong, B. M., 2011. A Theory of Financial Liberalization: Why are Developing Countries so Reluctant? World Economy 34, 1106-1123.

Gurgul, H., Lach, L., 2014. Globalization and Economic Growth: Evidence from two Decades of Transition in CEE. Economic Modelling 36, 99-107.

Jakšić, M., 1997. Globalizacija i makroekonomska politika, u: Jakšić, Miomir, (red.). Ekonomska politika stabilizacije, Ekonomiski fakultet, Beograd.

Jensen, T., Sandström, J., 2011. Stakeholder theory and globalization: the challenges of power and responsibility. Organization Studies 32, 473-488.

Johansen, S., Juselius, K., 1990. Maximum Likelihood Estimation and Inference on Cointegration with Applications to Demand for Money. Oxford Bulletin of Economics and Statistics 52, 169-210.

José, A. F., António, C. M., Cátia, L., 2019. The Impact of Financial Development and Globalization on Economic Growth: Evidence from a Macro Panel of Ten Countries. Asian Economic and Financial Review 9, 366-388.

Kilik C., 2015. Effects of Globalization on Economic Growth: Panel Data Analysis for Developing Countries. Economic Insights - Trends and Challenges. Available from: <upg-bulletin-se.ro/old_site/archive/2015-1/1.Kilic.pdf>. [11 August 2018].

Latif, Z. Latif, S. Ximei, L. Pathan, Z. H., Salam, S., Jianqiu, Z., 2018. The dynamics of ICT, foreign direct investment, globalization and economic growth: Panel estimation robust to heterogeneity and cross-sectional dependence. Telematics and Informatics 35, 318-328. 
McMichael, P., 2000. Development and Social Change: A Global perspective, Pine Forge Press.

Mittelman, J., 2006. Globalization and Its Critics, in: Stubs, Richard and Geoffrey Underhill, Political Economy and the Changing Global Order, Oxford: Oxford University Press.

Muhammad, M. R., 2015. Impacts of Globalization on Economic Growth Evidence from selected South Asian Countries Journal of Management Sciences, 2, 185-204.

Ohmae, K., 1990. Borderless World: Power and Strategy in the Interlinked World, New York: Harper Business.

Okungbowa, F. E., 2011. The impact of Foreign Direct Investment and Domestic Investment on the Nigeria Economy. West African Social and Management Sciences Review (WASMSR) 2.

Ojeka, J. M., 2004. Globalization and the third world countries. Article in the Sign Magazine, PP 14. Available from: 〈http//en.wikipedia.org.wiki/globalization〉. [11 August 2018].

Oyewale, I. O., Amusat, W. A., 2013. Impact of Globalization on Poverty Reduction in Nigeria. Interdisciplinary Journal of Contemporary Research in Business 4, 23 31.

Parisa, S., Hashem, J. S., 2014. Globalization and Economic Growth: Empirical Evidence on the Role of Complementarities. PLoS ONE 9(4): e87824.

Pisi, B. T., 2018. The Impact of Globalization on Economic Growth in Asia-Pacific. Asia Pacific journal of Advance Business and Social Studies 4, 79-85.

Polasek, W., Sellner, R., 2011. Does Globalization Affect Regional Growth? Evidence for NUTS-2 Regions in EU-27. Economics Series 266, Institute for Advanced Studies. Available from: <http://irihs.ihs.ac.at/2057/>. [11 August 2018]. Rao, B. B., Tamazian, A., Krishna, V. C., 2011. Growth effects of a comprehensive measure of globalization with country-specific time series data. Applied Economics 43, 551-568.

Saibu, M., Akinbobola, T., 2014. Globalization, Foreign Direct Investment and Economic Growth in Sub Saharan Africa. Journal of Economics and International Finance 6, 62-68.

Srinivasan, T. N., Bhagwati, J., 1999. Outward-orientation and development: Are revisionists right (Tech. Rep.). Center Discussion Paper. Available from: < link.springer.com/chapter/10.1057/9780230523685_1>. [11 August 2018].

Umo, U. J., 2007. Economics. An African Perspective Millennium. Text Publishers ltd Lagos. 
UNCTAD, 2018. World investment Report 2018. United Nations. on Trade Available form: <unctad.org/en/PublicationsLibrary/wir2018_en.pdf>. [11 August 2018].

Upali, P., 2017. An Introduction to the Theoretical Perspectives of Globalisation Journal of the Humanities and Social Sciences 12,

Villaverde, J., Maza, A., 2011. Globalization, Growth and Convergence. The World Economy. 34.

World Bank. 2018. World Development Indicators. Washington D.C.

Ying, Y.-H., Chang, K., Lee, C.-H., 2014. The Impact of Globalization on Economic Growth. Romanian Journal of Economic Forecasting 17, 25-34. Available from: <ipe.ro/rjef/rjef2_14/rjef2_2014p25-34.pdf>. [11 August 2018].

Zoran, S., 2008. Globalization: Theoretical Perspectives, Impacts and Institutional Response of the Economy. Facta Universitatis Series: Economics and Organization 5, 263-272. Available from: <facta.junis.ni.ac.rs/eao/eao200803 /eao20080309.pdf>. [11 August 2018]. 